\title{
Educational Policy
}

http://epx.sagepub.com/

\section{"More Justice" : The Role of Organized Labor in Educational Reform John S. Rogers and Veronica Terriquez \\ Educational Policy 2009 23: 216 \\ DOI: $10.1177 / 0895904808328529$}

The online version of this article can be found at:

http://epx.sagepub.com/content/23/1/216

\author{
Published by: \\ (\$) SAGE \\ http://www.sagepublications.com \\ On behalf of: \\ Politics of Education Association
}

Additional services and information for Educational Policy can be found at:

Email Alerts: http://epx.sagepub.com/cgi/alerts

Subscriptions: http://epx.sagepub.com/subscriptions

Reprints: http://www.sagepub.com/journalsReprints.nav

Permissions: http://www.sagepub.com/journalsPermissions.nav

Citations: http://epx.sagepub.com/content/23/1/216.refs.html 


\section{"More Justice"}

\section{The Role of Organized Labor in Educational Reform}

John S. Rogers

Veronica Terriquez

University of California, Los Angeles

This article explores the potential role of low-wage service sector unions in engaging in equity-minded school reform. The members of many such unions are parents of children attending poorly resourced public schools. In seeking to address the interests of their members, labor unions can draw upon resources, organizing strategies, and political relationships to contribute to grassroots campaigns for educational equity. Data gathered in Los Angeles from labor and civic leaders, as well as janitors belonging to the Service Employees International Union Local 1877, reveal possibilities for low-wage service sector unions to build alliances around educational reform issues and support their members' individual capacities to advocate for their own children in schools. At the same time, low-wage service sector unions face challenges to participating in school reform efforts, including prioritizing education issues among other competing interests and identifying common ground with teachers' unions.

Keywords: labor, organizing; school reform; equity

[When the] SEIUs, the HEREs of the world . . . get involved [in educational reform] it sends a different message than your traditional bargaining units who simply are involved around the bread-and-butter issues of pay [and] health care and don't ever . . . really talk about issues of educational equity and access. ... [The service sector] unions have a different say because their kids attend the schools.

Luis Sanchez, school board staff member

\footnotetext{
Authors' Note: Research for this article was supported by the University of California Labor and Employment Research Fund and the Institute for Research on Labor and Employment at the University of California, Los Angeles. The authors would like to thank Ramon Martinez and Rema Reynolds for research assistance on this article.
} 
Let's say a [service union] local that had X number of members in a particular school called a meeting of the union . . . [and used] that already existing network and . . . community of interests between those workers at a school. They could then work with the teachers and other workers at that school, as well as other parents. They could be a bulwark for organizing parents within that school.

Joel Jordan, teacher union organizer

The [service sector] unions are made up of [thousands of] people. So if you can put that number of people in the streets on an issue, then you can get somebody's attention and . . . maintain that attention until [you] get what [you] want.

Goldie Buchanon, parent organizer ${ }^{1}$

Low-wage service sector unions have rarely garnered the attention of educational officials, civic elites engaged in educational reform, or scholars of the politics of education. Yet there is some reason to believe that change is afoot. During the past 15 years, service sector unions in several cities have demonstrated a willingness and capacity to mount substantial political campaigns to enhance the position of workers and improve public services. Although, to date, they have not moved in force into education policy, low-wage service sector unions hold a distinct set of educational interests, maintain considerable political resources, and have the capacity to deploy innovative and potentially powerful tactics. This article draws on data collected in Los Angeles to explore the potential for these unions to become an advocacy force to reckon with in 21 st century politics of education.

Consider the case of the janitors union in Los Angeles, the Service Employees International Union (SEIU) Local 1877. The vast majority of the 8,000 members of SEIU Local 1877 are immigrants with relatively low levels of formal educational attainment. In a membership survey from 2006, more than nine in ten respondents reported they were born outside of the United States, mostly in Mexico, El Salvador, and Guatemala. Only one in four members indicated that they hold a high school degree. Most of these janitors are parents of students in Los Angeles schools. And like many low-wage workers in Los Angeles, members of Local 1877 view their children's education as the key to long-term financial security for their families. In a survey conducted by the union, three in four janitors reported that they expect their children to graduate from college.

These high aspirations are not matched by quality learning opportunities for the children of Local 1877. The relatively high levels of residential segregation among Local 1877 members mean that many janitors send their 
children to a fairly small group of schools. Approximately half of Local 1877's members live near 17 of Los Angeles County's 180 comprehensive high schools. ${ }^{2}$ In Los Angeles County, as in many economically and racially segregated metropolitan areas, residential location is correlated with the resources available in local schools (Orfield \& Eaton, 1996). The 17 high schools closest to Local 1877 members are highly segregated; Latino and African American students compose $90 \%$ or more of the population in 14 of the schools. In 15 of the 17 schools, more than half of the students are eligible for free or reduced-price lunch. Furthermore, these 17 schools provide notably less resources than other public schools in California. They are five times more likely than other schools in the state to experience severe shortages of qualified teachers. They are seven times more likely to be designated by the state as "critically overcrowded." It is thus not surprising that these high schools have low graduation and college eligibility rates. For every 100 students who entered these 17 high schools in fall 2001, fewer than half graduated four years later and less than one in six graduated having completed the requirements for four-year colleges. ${ }^{3}$ This poor performance is not the exclusive domain of high schools. We estimate that more than two in three of the public schools attended by children of Local 1877 members have been designated by the state of California as Program Improvement Schools because of the schools' failure to meet adequate yearly progress as specified by the No Child Left Behind Act. ${ }^{4}$

Given the conditions and performance of public schools serving janitors' families, it is not surprising that Local 1877 organizer Aida Cardenas calls educational reform "the civil rights issue . . . of our generation." Cardenas's claim is echoed by members of Local 1877. More than two in three members surveyed by the union strongly agreed with the statement "Local 1877 should become involved in improving the education system for members children." Fewer than 5\% of members disagreed, even though a number of members do not themselves have children. Furthermore, when asked to select the most important issue for the union to focus on (beyond wages, benefits, and work site concerns), Local 1877 members chose education reform above other critical issues such as immigration reform and access to affordable housing.

The interest of members in educational reform is significant because Local 1877 (formerly part of Local 399) has a history of joining and winning political campaigns. In the late 1980s and 1990s, the so-called Justice for Janitors campaigns challenged both the building owners and contractors and the 
conventional wisdom that immigrant workers in a decentralized, deunionizing industry could not be organized. These campaigns drew on new strategies of mass mobilization and coalition building with a variety of civic and religious groups. Local 1877 also deployed highly visible organizing tactics including public protests and marches, acts of civil disobedience (e.g., blocking traffic during Los Angeles rush hour), street theater, hunger strikes, and aggressive efforts to garner media attention. The janitors won union recognition, won improved wages and benefits, and garnered substantial political influence in the city at large (Milkman, 2006; Waldinger et al., 1998). Local 1877's victory has been characterized as "the single most important organizing success story of the US labour movement in the late twentieth century" (Erickson, Fisk, Milkman, Mitchell, \& Wong, 2002, p. 544).

Yet for all of this potential, Local 1877 is only beginning to explore its role in educational reform in Los Angeles. With the notable exception of the teachers union, most sectors of organized labor have played little or no role in shaping Los Angeles educational policy and practice during the past two decades. The United Teachers of Los Angeles (or UTLA) has been the primary voice of labor on education policy issues. The only other union that consistently participates in educational policy discussions is the Associated Administrators of Los Angeles (AALA). However, AALA's influence pales in comparison to that of UTLA. Some other unions, particularly those in the building and trades sector, have joined policy discussions about career and technical education that they see affecting workforce development. Finally, SEIU Local 99, representing classified staff in the Los Angeles Unified School District (LAUSD), has been a significant force in its own contract negotiations with the district. But it has yet to assert a formal role in discussions about educational practice.

There are many reasons why educational reform has been the near exclusive domain of teachers unions. Many service sector unions defer educational questions to teachers unions as an acknowledgement of professional expertise. Local 1877 organizer Aida Cardenas explained the prevailing view has been "that's their field, that's their expertise, they're the ones that know." In addition, low-wage service sector unions generally have focused their energies on bread-and-butter concerns with salary, benefits, and working conditions or on other issues such as immigrant rights.

In the remainder of this article, we explore the possibilities for service sector unions to become significant players in educational reform. We consider, as well, the potential significance of such a shift for organized labor, equity educational reform, and grassroots mobilization for social justice. 
This article unfolds in four sections. The first section builds a case for why organized power is necessary to promote equity reform. The second section examines the potential role of organized labor in creating organized power for educational reform. This section draws on cross-national research on social justice unionism, focus groups with Los Angeles residents, and interviews with labor and civic leaders in Los Angeles to consider the rationale and possibilities for labor-community partnerships for educational justice. The third section returns to the story of Local 1877 in the form of a case study examining the emerging educational activism of individual members and the incipient efforts to forge coordinated action. The fourth section takes a more sober note, considering the challenges of engaging low-wage service sector unions in educational reform. We close with a few thoughts on the prospects for organized labor to surmount these challenges.

Our study draws on qualitative and quantitative data collected between 2006 and 2008. We conducted 11 interviews with labor and civic leaders in Los Angeles about the role of service sector unions in educational reform. The labor leaders represented such diverse constituencies as teachers, carpenters, janitors, and school cafeteria workers. We also gathered individual interview data from Local 1877 staff and rank-and-file 1877 leaders and conducted 40 in-depth interviews with 1877 members on their labor union involvement, parental school participation, and interest in union sponsored educational programming. We use data from two focus groups with union members regarding Local 1877's role in supporting the education of members and their children. Furthermore, we draw on field notes gathered from our participation in the union's education-related meetings, observations of the union's public actions, and participant observations of nine days of parent education workshops targeting Local 1877 members with children.

We also report data from two different surveys with 1877 members. The first survey was administered by the union (with our technical assistance) between November 2006 and January 2007 to 386 members at various job sites and at the union hall. The purpose of this initial survey was to gauge member interest in school reform and various education-related programming. In summer 2007, we conducted a telephone survey of a random sample of union members with children. ${ }^{5}$ Our survey contains a sample of 378 respondents-221 women (58\%) and 157 men (42\%). ${ }^{6}$ Data collected from this second survey include information on members' demographic background, labor union participation, involvement in the school of one randomly selected school-aged child, and other information. 


\section{Why Equity Educational Reform Requires Organized Power}

In the past few years, we have joined our colleague Jeannie Oakes in arguing that the problems facing urban school systems such as Los Angeles cannot adequately be addressed through conventional reform strategies that deemphasize politics and advocacy and highlight organizational change and technical expertise (Oakes \& Rogers, 2006, 2007; Oakes, Rogers, Blasi, \& Lipton, in press; Rogers \& Oakes, 2005). ${ }^{7}$ Such strategies are dominated by three flawed assumptions. The first holds that high-quality and equitable schools can be created by working exclusively within the educational system. The second is that inequalities are sustained by a lack of information about education opportunities or appropriate reform technologies. The third assumption, following from the first two, is that once policy makers and educators understand the problem and how to address it, they will act to improve and equalize schooling. All of these assumptions presume that poor and unequal schooling is at odds with deeply held values of opportunity and fairness.

Rather than conflicting with our cultural values, inequality is endemic to the logic of our society and to the role schools play in it. At least three powerful cultural "logics" shape how people make sense of the schooling that society provides to various groups of students: the logic of scarcity, the logic of merit, and the logic of deficits. The logic of scarcity assumes that our society can afford only limited investments in public life and public education. Hence, the supply of "quality" schooling cannot keep pace with increased demands for more and better education that is needed for good jobs and middle-class lives. The logic of merit assumes that young people compete for scarce schooling advantages with their talents and effort in a context of equal opportunity and are rewarded with educational opportunities commensurate with the degree to which they deserve them. The logic of deficits presumes that low-income children, children of color, and their families are limited by cultural, situational, and individual deficits that schools cannot alter. That these children get fewer education and social advantages is a result of these deficits and not of structures within the educational system.

Together, these three narratives make it difficult for Americans to see that inequality is the result of flawed policies and structures rather than attributes of individual children and their families. In other words, limited opportunities, educational "winners" and "losers," and unalterable deficits all make inequality seem sensible and normal to people across political and socioeconomic spectra. This normalization of the status quo eases public pressure for 
equity reform. There is no need to challenge powerful vested interests or to leverage new resources (let alone redistribute existing resources) if prevailing outcomes are reasonable and inevitable. Parents and community members may express frustration with educational conditions, but not in a manner that prompts sustained political response. The logics of scarcity, merit, and deficit thus support a quiescent (though often dissatisfied) public.

Altering the politics of education requires confronting these logics and energizing members of the public who are poorly served by existing schools. And this points to the importance of grassroots mobilizing to achieve more equitable schooling. Grassroots and activist organizations, seeking to build the power of low-income communities, engage students, parents, and community members in powerful actions aimed at exposing and disrupting schooling inequalities. These groups routinely target the prejudices and politics that sustain unequal schooling. Because grassroots "reformers" are also those who experience the broad range of social, economic, and political inequality, their centrality in reform forces the connections between education and broader social issues and struggles.

Organized grassroots groups often use a repertoire of social movement actions - actions that persuade with the weight of their numbers, their capacity for material damage, and the garnering of sympathy and support by bearing witness (Della Porta \& Diani, 1999). Actions based on the power of numbers include marches, rallies, petitions, letter writing, and mobilizing voters. Like democratic political processes, such actions attempt to persuade elites that there is large public support for or against a particular policy. Actions reflecting a theory of "material damage" include boycotts, strikes, blocking traffic, disrupting business, and, at the extreme end, damage to property. The theory here is that actions will be powerful and persuasive if they cause some noticeable impact on the economy or disrupt normal processes. Actions based on "bearing witness" include forms of civil disobedience such as hunger strikes, burning draft cards, refusal to pay taxes, and chaining oneself to a tree. These strategies seek "to demonstrate a strong commitment to an objective deemed vital for humanity's future" by engaging in behaviors that involve personal risk or cost (Della Porta \& Diani, 1999, p. 178). Together, these actions enable grassroots groups to leverage their size, networks of support, and moral standing to secure resources and forge empowered relationships with public officials.

During the past decade, we have seen a significant growth in both grassroots community organizing for educational reform and in studies of this emerging phenomena (Warren, in press). Scholars from the disciplines of sociology, political science, and education have examined struggles for 
educational justice as a strategy for equity educational reform and civic engagement (Noguera, Ginwright, \& Cammarota, 2006; Orr, 2007; Warren, 2001). Much of this literature (e.g., Shirley, 2002) has focused on communityand/or faith-based organizations as the primary agents for building power and effecting policy changes. Aside from an occasional reference to teachers unions, little attention has been paid to the potential role of labor unions in grassroots campaigns for educational reform. ${ }^{8}$

The importance of organized labor has been a more salient theme in the literature on education and social movements. In her seminal book Radical Possibilities, Jean Anyon (2005) argued that, because the problems of urban schools are embedded in the political economy of cities, lasting and significant changes in educational opportunity require radical changes outside of schools, which in turn demand broad-based social movements. Anyon envisioned an important role for progressive labor unions in building such a movement (p. 160). Jeannie Oakes and John Rogers (2006, p. 172; also see Oakes et al., in press) similarly argued that the best possibility for advancing educational justice lies in social movements that simultaneously address the need for quality schooling and the needs for decent paying jobs, access to health care and housing, and so on. Oakes and Rogers hypothesized that the renewed focus on organizing within sectors of the labor movement with a large presence of working mothers may create opportunities for movement activity that brings together organized labor and communitybased organizations focused on educational reform.

\section{Social Justice Unionism, Organized Power, and Educational Reform}

Although scholars in the field of labor studies have not yet addressed the potential of service sector unions to participate in educational reform, they have written more generally about efforts of organized labor to forge coalitions with community organizations to address the needs of working people. For example, Frege, Heery, and Turner (2003) documented an array of coalitions in Germany, Britain, and the United States "between trade unions and other nonlabor institutions in civil society, including community, faith, identity, advocacy, welfare and campaigning organizations." Labor scholars term such coalition-based activity social movement unionism to highlight the importance of collective mobilization to "wrest concessions from corporations and corporate-dominated governments" (Nissen, 2004, p. 67). 
Social movement unionism has emerged against the backdrop of globalization and neoliberal economics, which have combined in recent decades to erode the welfare state and shrink union membership. Union membership has declined from $35 \%$ of the U.S. workforce in the 1950s to less than $15 \%$ today (Fine, 2005, p. 153). During much of this period of decline, labor organizations adopted more conservative goals and tactics. They embraced top-down organizing campaigns with minimal participation from rank-and-file members, practiced nonconfrontational tactics, and, with few exceptions (e.g., in the public sector), did not engage in extensive efforts to organize new members (Milkman \& Voss, 2004; Voss \& Sherman, 2000).

Faced with harsher conditions and declining power, some unions have responded to the crisis in labor by combining new organizing strategies with the radical tactics used in the 1930s when the U.S. labor movement was at its strongest. Unions, especially those representing workers in industries that cannot be outsourced, have increasingly used massive street demonstrations, direct action, worker mobilizations, and sophisticated campaigns to garner more strength and power. Stepped up activism by unions was strongly supported by a turnover in leadership in the AFL-CIO in 1995. John Sweeney, the newly elected president, called for unions to use $30 \%$ of their resources for new organizing. Resulting changes have led to the revitalization of segments of the labor movement, greater emphasis on the leadership development of rank-and-file workers in some unions, and increased visibility of worker mobilizations motivated by social justice, particularly in urban centers (Milkman \& Voss, 2004; Voss \& Sherman, 2000).

This new, more militant unionism has looked to effect policy changes in nontraditional areas such as international labor standards and immigration to build its base and hence its power. These campaigns have prompted unions to seek partners outside of labor. Frege et al. (2003) explained, "As the agenda of interest representation extends beyond the immediate employment relationship, unions almost inevitably become drawn into contact with preexisting campaigning and advocacy organizations."

Coalition building has the potential to revitalize unions and the broader labor movement in at least three ways. First, coalitions extend the power of unions beyond their existing membership. This potential to augment an existing base of support is critical in sectors with low union density. Second, coalitions between trade unions and community organizations around issues of public concern can foster union-friendly sentiment in the broader public. As Nissen (2004) argued, a "major task for organized labor in this country is to change the cultural climate so that union rights become a cause to which large percentages of the population are dedicated" (p. 68). Third, 
participating in grassroots mobilizations generates political energy (confidence, commitment, and relationships) that organizers can leverage in future organizing campaigns.

While acknowledging the challenges of building coalitions, labor scholars have tried to identify conditions that encourage unions to forge partnerships in the community. Tattersall and Reynolds (2007) pointed to the importance of building coalitions around a common purpose that can foster "interorganizational participation." They argued that a common purpose is most effective when it "is framed as a social vision for working people as a whole" (p. 79). Turner's (2007) comparative analysis suggested that coalitions are more likely to arise in particular urban centers. Social justice unionism, he argued, emerges when key union leaders make strategic choices that take advantage of the "opportunity structure"-the institutional openings and social context (p. 4). New coalitional and grassroots strategies, for example, are particularly responsive to urban areas with sizeable service industries and a large immigrant workforce.

\section{What Can Service Sectors Unions Bring to Educational Reform?}

Low-wage service sector unions potentially can contribute to grassroots campaigns for educational reform through their resources, relationships, or knowledge and skills. Unions can leverage substantial resources to effect change. By pooling funds from large numbers of workers, labor unions can turn a relative weakness of low-wage workers into a relative strength. Tattersall and Reynolds's (2007) international study of labor-community coalitions found that "out of all coalition partners, unions usually have the largest number of resources at their disposal; they usually have the largest number of members and the largest base of independent funds" (p. 78). In addition to their capacity to disperse and direct funds, many labor unions also bring a powerful communications infrastructure to campaign work. The Los Angeles School Board's Luis Sanchez noted that unions like UNITE HERE and SEIU have "member to member capability where they can send out information to their membership, some that have 30,000 to 90,000 members. They can educate them about these issues."

Furthermore, by mobilizing a sizeable membership, unions can generate a prized political resource-high levels of participation in campaigns. Several Los Angeles labor and civic leaders noted the potential for unions to bring out large numbers of members to grassroots actions. UTLA's Joel Jordan envisioned service sector unions underwriting the efforts of existing educational reform groups: 
There are community-based organizations that help parents get organized, but they . . . don't have the resources that many of these unions have, both in terms of staff and in terms of their overall resources. . . . So the unions could play a very valuable role.

Along with activating resources, low-wage service sector unions can use their extensive social and political relationships to contribute to campaigns for educational reform. Tattersall and Reynolds (2007) argued that within social movement unionism, organized labor often draws on the social networks of both members and unions to "enfranchise the coalition's agenda" (p. 78). Union locals such as Local 1877, with long histories of working with community groups, are able to bring new partners into campaigns. Moreover, they can draw on existing networks with elected officials. According to SEIU's Aida Cardenas, these networks create "political leverage, political clout [that can] . . . help put issues on a platform or actually have some sort of decision-making power."

Low-wage service sector unions also contribute valuable knowledge and skills to their coalitional work. This contribution is noteworthy because it inverts the commonly held view that community groups provide the "brains" and unions the "muscle." Indeed, the literature on union-community coalitions speaks of unions turning to community groups for expertise on policy issues but does not highlight the understanding that unions bring to these partnerships (Frege et al., 2003). Many service sector unions bring sophisticated understandings of organizing and campaign development that can be of great use to educational reform efforts. Aida Cardenas pointed out that at SEIU "we know how to build a base and we know . . . how to build a program and engage and give members ownership." UTLA's Alex CaputoPearl similarly argued that SEIU and UNITE HERE can teach education organizers about "tactics and approaches used in one-on-ones, leadership development, [and issues such as] how to deal with people's fear."

Los Angeles Deputy Mayor Larry Frank was particularly expansive in his explanation of the special knowledge that unions such as SEIU and UNITE HERE bring to political work:

These unions have the ability to implement something called a strategic campaign. This approach analyzes the political landscape, understands leverage, and can move a very large public campaign using multiple strategies. Their message and actual work is by design focused on a broad public benefit, instead of a narrow private interest. 
UTLA member Alex Caputo-Pearl made a related point in acknowledging the ability of SEIU and UNITE HERE to integrate research into their campaigns. These unions are able to "identify what some broader trends are going to be in the economy and industry" and how these trends "might shape schooling." Caputo-Pearl believed these and similar insights are "really critical" for future educational campaigns.

Alongside the skills embodied in a union's staff are the skills that activist unions instill in their membership. Unions that engage members in contentious political activity provide members with specific advocacy and organizing skills that they can apply to other contexts outside of a laborrelated campaigns. For example, workers in unions learn how to exercise their rights, file grievances, organize strikes or other collective actions, and appeal to government officials. McAdam, Tarrow, and Tilly (2001) explain that experience with activism provides participants with scripts or repertoires. In applying these repertoires to problems they face, individuals "do not simply invent an efficient new action or express whatever impulses they feel, but rework routines in response to current circumstances" (p. 138).

Participation in labor unions can be an empowering experience that shapes individuals' interests and values. Labor unions can provide workers opportunities to learn about their rights and how to exercise them individually or collectively in both the workplace and in other civic arenas. Moreover, as Anyon (2005) explained, experiences such as protesting, marching, and making political demands can shape an individual's political identity and commitments. In particular, union members' collective participation in militant workplace activities can influence their political consciousness, attitudes, and values (Fantasia, 1989). Prior experience in labor organizations that engage workers in interest-based social and political activism thus may lend itself to future activism in the arena of educational politics.

\section{Why Service Sector Unions Have a Stake in Education Reform}

Traditionally, unions have represented the interests of workers at the workplace, seeking to secure decent wages, benefits, and work conditions. Local 1877's Aida Cardenas noted that her union seeks "to stabilize your job, to make it full-time, to have health insurance, to have vacations, to have a livable wage." She called these core conditions the "basics of bringing folks out of poverty." During the past two decades, some unions have begun to define workers' interests more broadly. Saira Soto, staff member at Local 721 representing public sector service workers, explained that SEIU looks 
"at our members as a whole, because . . . at 5:00 they go home and belong to a community that is affected by low wage work [and] the lack of affordable housing." Unions thus have an interest, reasoned UTLA's Joel Jordan, "in improving the overall quality of life" of their members.

Beyond the workplace, low-wage service workers' lives are shaped by policies that determine both the short-term and long-term opportunities for their families. Issues such as access to decent affordable housing speak to workers' present needs. Immigration reform has been a critical issue for many low-wage workers because it potentially addresses both immediate threats to their livelihood and future possibilities for economic mobility and political power (Wong \& Munoz, 2004). Education primarily represents a long-term interest of low-wage service workers. ${ }^{10}$ Aida Cardenas argued that although successful union campaigns can provide low-wage service workers with marginal increases in income and benefits, they cannot move families into the middle class: "So now, we're looking at how do we really look at the next step for the future for those families, which is their . . . children's education." Cardenas believed that Local 1877 members see a direct relationship between these educational aspirations and their daily work.

It is why they work so hard every night and fight for decent working conditions and being rewarded for their work, so that they can provide something for their kids and their kids to go onto college and get a degree and have a much better life than they've lived.

It is important to consider the institutional interests of the unions alongside the interests of their members. Unions want to expand their membership and build their power and influence. Progressive unions also want to effect social change on behalf of their members. There is an iterative relationship between these two sets of interests: Struggling for and achieving social change can help unions become more powerful. In his cross-national study of unions participating in coalitions, Lowell Turner (2007) found that "unions build on bases in society well beyond the workplace to gain public support and build new political power that can also feed back into workplace power" (p. 4).

Turner's conclusion resonates with the findings from a series of focus groups convened by the Institute for Industrial Relations of the University of California, Los Angeles (UCLA) in 2005 to explore the public's attitudes toward labor. A random sample of eligible voters in Los Angeles County reported generally unfavorable views about organized labor. Most participants in the focus groups-including union members themselves-viewed 
unions as acting in narrowly self-interested ways that often undermined public purposes, for example, by protecting "bad" workers from being fired. Although a sense of indifference or hostility to unions pervaded the focus groups, these attitudes changed when focus group facilitators shared specific examples of unions standing up for nonmember workers. The examples were most persuasive when there was an explanation given for why unions might be working on issues beyond the workplace; for example, union members are parents of children in public schools (UCLA, Institute of Industrial Relations, 2006).

Los Angeles Deputy Mayor Larry Frank made a related argument about the interests of service sector unions in Los Angeles:

There are two primary goals that unions must address to build their political power. The first is focused on getting back their moral authority and the second is their need to organize the unaffiliated workers. For the new labor movement, those two interests are interlinked in order to get the power to be meaningful in the public arena. They need union density to elevate their voice. And they need moral authority, which comes form a focus on public benefit, to build their base.

For Aida Cardenas, these dual goals represent an "opportunity" for the union "to demonstrate leadership." Cardenas believed that, by partnering with community organizations around issues like educational reform, SEIU establishes credibility and a base of good will. As SEIU takes on big social issues, it gains "visibility within the community" which can "help us organize tomorrow." Cardenas concluded, "If a union organizer from SEIU comes out selling a tour about organizing with SEIU, it helps. So I'm thinking the full circle."

\section{The Case of Local 1877}

Turner (2007, p. 6) highlighted two factors that shape whether coalitions between unions and community groups emerge- (a) the opportunity structure set by a particular political, economic, and institutional context and (b) the agentive decisions of key union leaders and membership. Opportunity structure refers to strategic openings created by shifts in who holds authority and legitimacy or who can leverage political resources. Such openings might be created by divisions among a city's power brokers or rapid demographic change. Agency refers to the choice of leaders to take advantage of these new opportunities. Tattersall (2006) built on Turner's work to argue that a union's agency is shaped by its historic identity. She is worth quoting at length: 
Unions with a history of militancy, ideological radicalism or broad interest representation beyond wages and conditions may be more likely to engage in future collaboration. Ideologically progressive unions may find it easier to cultivate a common interest with community organizations if they are committed to campaigning on issues beyond wages or conditions. Similarly, if union collaboration is a familiar tactic_-part of a union's "repertoire of contention"- - then it is more likely to be used as a strategy in the future.

\section{Opportunity Structure for Union Engagement in Educational Reform}

Four strategic openings have emerged in recent years that create an environment conducive to union-community partnerships for educational reform in Los Angeles: (a) the election of union-friendly Latino leadership in City Hall and in the school district, (b) the rise of progressive leadership in the teachers union, (c) the power of the County Federation of Labor, and (d) the residential concentration of union members around particular public schools.

A first element of Los Angeles's opportunity structure is the emergence of city and school board officials with strong ties to the low-wage service sector unions. Antonio Villaraigosa, Los Angeles's first Latino mayor in more than a century, has deep labor roots as a former UTLA labor organizer. He was elected with a tidal wave of support from immigrant and service sector workers who remain core to his coalition. Monica Garcia, the school board president, has cultivated a strong relationship with several service sector locals. She aggressively sought out the endorsement of SEIU and subsequently championed a board resolution that provided health benefits to cafeteria workers represented by SEIU Local 99.

Second, Los Angeles's opportunity structure is shaped by the presence of a progressive teachers union. In 2005, an insurgent slate of candidates swept the key executive offices at UTLA. This group of leaders was elected to another three-year term in February 2008. Perhaps equally important, the progressive slate ("united action") has scored victories at the local level as well, winning more than $80 \%$ of the seats of the regional leadership of the union, all of which are held by full-time classroom teachers (A. CaputoPearl, personal communication, February 24, 2008). A key initiative of the new UTLA leadership has been to initiate outreach to organizations in lowincome communities of color. For more than a year, UTLA has convened meetings with 10 different community groups. As Caputo-Pearl noted, "The model is there to bring other unions in . . . who want to get really involved in educational reform discussions." 
Third, the Los Angeles County Federation of Labor plays a major role in shaping opportunities for union activism and labor-community partnerships in Los Angeles. Representing more than 345 affiliates and 800,000 workers, the "County Fed" is a major force in Los Angeles's economy and political life (Frank \& Wong, 2004, p. 156). Since the mid-1990s, the County Fed has convened different sectors of organized labor and brokered coalitions among labor and community organizations (Frank \& Wong, 2004 , p. 171). It has leveraged union power to advance the candidacy of several key elected officials and, in turn, been able to call on these officials to support labor friendly policies. As UTLA's Alex Caputo-Pearl pointed out, the County Fed's leadership is committed to building a "broader social movement for economic and social justice." In addition to providing an infrastructure that supports social movement unionism, the County Fed is particularly responsive to those low-wage service sector unions that might consider becoming engaged in educational reform.

Finally, the intense segregation of Los Angeles's communities by race, immigrant status, and income creates residential concentrations of union members in areas around particular public schools. For example, Local 1877 members are residentially concentrated in a handful of predominantly low-income Latino communities in Los Angeles County. Figure 1 shows the residential concentration of Local 1877 members in the Los Angeles Unified elementary school catchment areas. The map indicates that more than 50 Local 1877 members live within the attendance boundaries of 11 Los Angeles Unified elementary schools, whereas between 25 and 49 union members live within the boundaries of about 26 elementary schools. Although not all Local 1877 members have children attending local elementary schools, such geographic concentration can potentially create opportunities for parents to join with fellow union members to advocate for school reform, especially given that many already have the skills useful for school-based problem solving and parent organizing. We emphasize potential participation because most members do not yet know whether other union members send their children to the same school as their own children. Local 1877 members are scattered across different work sites throughout Los Angeles County, and union functions provide limited opportunities for members to get to know each other as parents. Yet the opportunity for parents at the same school to collaborate with each other could be realized if the union made a concerted effort to help establish school-based networks of members. 


\section{Figure 1}

Residential Concentration of Local 1877 Members in Los Angeles Unified School District (LAUSD) Elementary School Attendance Boundaries

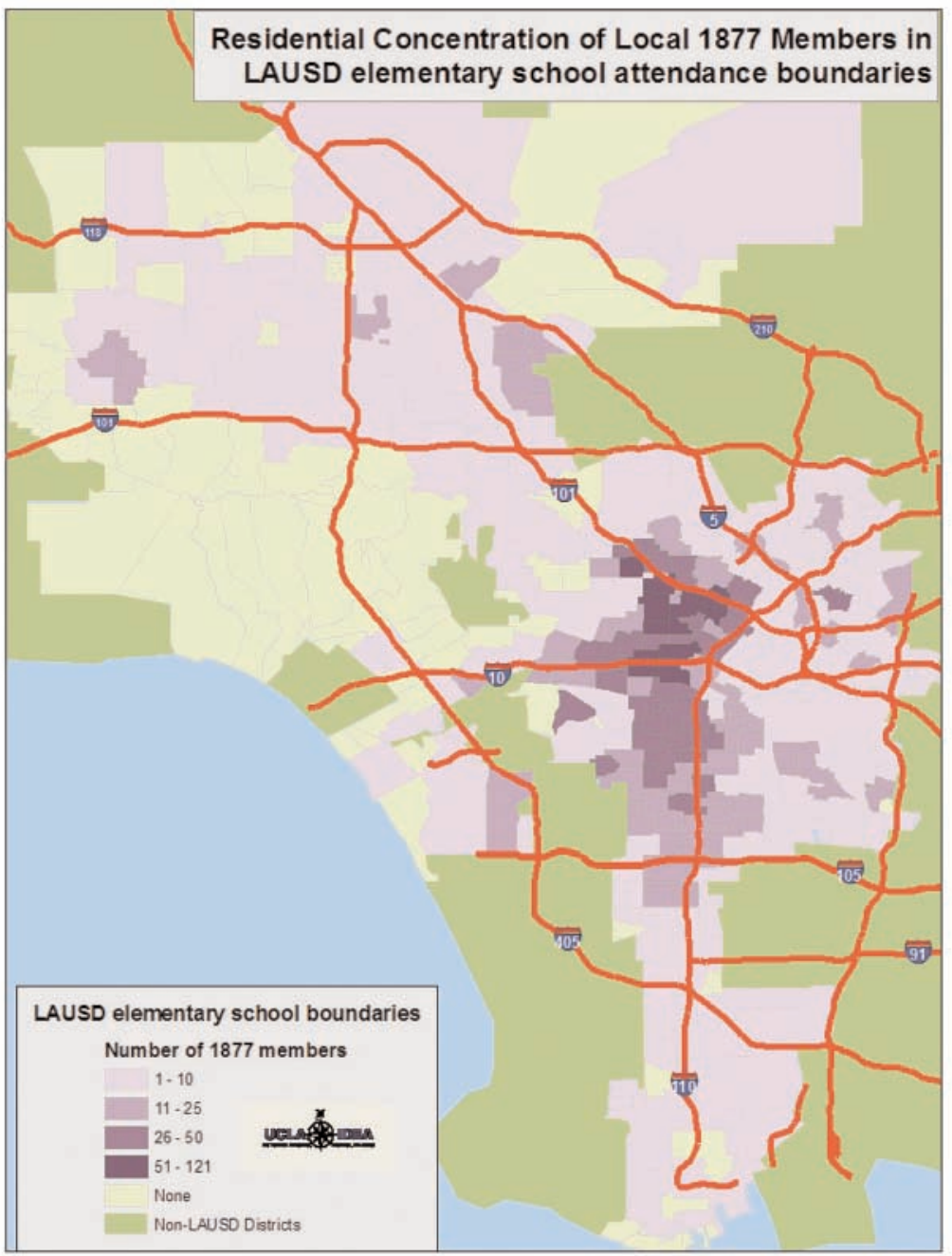




\section{Agency and Identity}

Since the early 1990s, SEIU Local 1877 has made headlines in Los Angeles for its successful Justice for Janitors campaigns. Throughout the years, the union has won higher wages, health care benefits, and other job protections for its largely Latino immigrant membership. Its highly visible organizing tactics include public protests and marches, acts of civil disobedience (e.g., blocking traffic during the Los Angeles rush hour), street theater, hunger strikes, and aggressive efforts to garner media attention. The union's organizing efforts have not been restricted to the five master contracts that it has negotiated within the past two decades on behalf of janitors. The union actively involves its members in immigrant rights' demonstrations, election campaigns, and other political activities.

Given the union's past and historic efforts to engage members in its activist efforts, it is not surprising that many Local 1877 members have taken steps-on their own - to improve their children's schools. Union members have participated in a range of school and community-based meetings focused on issues such as school overcrowding and substandard facilities. Individual Local 1877 members with children attending several different schools have reported collaborating with other parents to address student health and safety concerns at school sites. For example, when one parent found out that the drinking water at his child's school contained lead, he initiated a successful campaign to force the school district to provide uncontaminated water.

Participation in union-related activities provides many members with confidence and skills that enhance their participation in their children's schools. Several union members report that their participation in union activism has boosted their confidence and their ability to speak up and defend themselves and others. These parents note that, in the past, they have felt uncomfortable speaking in public and confronting authority figures, including school personnel. Yet participation in union meetings, marches, trainings, and other activities has increased their assertiveness. For example, Lucia, a rank-and-file leader, stated,

I was a very timid person, honestly, a very timid person. If I had to speak in public, I would turn red and would not know what to say. Getting involved in the [union] trainings has helped me become unafraid. . . . I believe that the union has played an important role in my life. I have learned a lot. It has given me confidence, it has helped me defend myself and speak to other people. ${ }^{11}$ 
Many Local 1877 members apply skills that they learn at the union to school-based advocacy and organizing efforts. One parent participated in the union's contract negotiations and learned negotiating skills useful for advocating for more tutoring for her son and other children. The story of Francisco, a Guatemalan immigrant with a sixth grade education, offers an example of how union experience enhances parents' school advocacy skills. Francisco arrived in Los Angeles in the late 1980s, obtained work as a janitor, and soon became involved in the Justice for Janitors campaigns. By the mid-1990s, he became a union steward and learned to help coworkers solve their grievances and mobilize them for union strikes and actions. As a shop steward, Francisco was required to keep track of workers' phone numbers and the information that they needed to resolve their problems or obtain a large turnout for a rally. Now that he is no longer the shop steward at work, he performs a similar function for parents at his children's schools.

Yes, my book over there is where I have all the numbers. I can look for it right now and tell you with whom I have spoken to, all the numbers [I have called]. And I know, for example, the big district right now is at 333 Beaudry [Los Angeles Unified District Offices]. Well then, I call over there and they are the ones that are in charge of administration for all the schools. If they don't help, you get in touch with Sacramento, and from Sacramento, they send an investigation and the whole thing gets bigger. Then the schools don't like that, not even the district, because then other problems arise, and the problems get bigger. ${ }^{12}$

\section{Possibilities for Joint Action Under the Union's Leadership}

To date, Local 1877 members have engaged in educational advocacy primarily as individual parents rather than as members of their union. Yet Local 1877 members have a long history of working together as members of the same labor organization to address specific work site problems, fight for a fair contract, and campaign for other political causes (immigrant rights, election of a labor-friendly candidate, etc.). Recently, the union has begun to respond to members' concerns about their children's education.

For example, the union has sponsored parent education workshops that provide members with additional information and skills to advocate for their children. At the request of membership, Local 1877 began hosting "Parent University" workshops to provide its immigrant workers a better understanding of the California public school system and the roles parents can play to support their children through the schooling process. Workshops included topics such as parent rights, school governance structures, understanding report cards and standardized tests, the college application process, 
resource inequalities in public schools, and the California education budget. These workshops provide useful information for parent advocacy efforts. For example, after learning that she and other parents had a right to translation at school events, one parent successfully advocated for interpreters at all parent meetings at her child's school.

Local 1877 used its most recent round of contract negotiations in spring 2008 to further support parental school involvement. Prior to negotiations, rank-and-file members expressed concern over conflicts that sometimes emerged between their work obligations and their desire to play a more active role at their children's schools. Many members reported that they were not given permission to leave work to attend back-to-school nights, parent conferences, and other school events. One parent was not allowed to attend her daughter's graduation. The members thus were interested to learn that an existing state law, the California Family-School Partnership Act, guarantees parents and guardians the right to take up to 40 hours off work each year to participate in activities at a child's school or day care facility. Recognizing that the act provided no meaningful enforcement mechanism, Local 1877's rank-and-file members and leaders reasoned that they could realize the law's lofty rhetoric by making specific reference to it in their labor contract. As a result, the union was able to secure a contractual commitment for janitors to be able to participate in their children's schools in accordance with the Children Family-School Partnership Act. In addition, Local 1877 conducted a Parent University training for parents on the act and created a brochure that could be disseminated to members to facilitate parental school involvement.

Local 1877 has directly and indirectly supported parents' roles in education by using the union contract to create a fund for worker education. As a result of the most recent janitors' contract signed in spring 2008, employers must now contribute three cents per hour worked per employee to provide workers with English classes at the union and at various job sites. This fund is also used for computer training and citizenship courses and may in the future be used for a GED program. Significantly, it supports the Parent University workshops.

\section{Challenges to Engaging Organized Labor in Educational Reform}

Thus far, we have told an optimistic story about the prospects for lowwage sector unions such as Local 1877 to become engaged in educational 
reform. We have argued that these unions have a strong interest in promoting educational equity, that they stand to contribute substantially to such efforts, and that the political and institutional environment presents unique opportunities for them to become part of educational justice campaigns. In this section, we temper some of that optimism. We highlight ongoing competition for time and resources and then turn to the thorny problem of turf battles among unions. We close with a few thoughts on a way forward.

A first challenge to engaging low-wage sector unions in educational reform is that these unions have many important demands on their attention. Noting these multiple demands, Joel Jordan of UTLA argued that unions such as 1877 need to prioritize their goals. But, as Aida Cardenas suggested, this is no easy task.

At 1877, we're breaking through in new industries; we're breaking through in sectors like security. We're trying to fight through the airports, which is not an easy place especially after $9 / 11$. We're outreaching into other parts of the country. . . . The challenge is that we want to do a lot because there's so much that needs to happen, so the challenge is keeping the focus; the challenge is having the resources to do everything you want to do.

A second, and related, challenge is that educational funding is often set in opposition to funds for other critical public services that affect low-wage workers. Union staffers such as Saira Soto face Solomonic choices about which policies to support. "There are too many things that need immediate attention so how do you push education over health care, how do you push health care over affordable housing, they are all extremely urgent and critical issues." The difficulty of these choices is compounded by state funding formulas that lock in funds for some services but not others and by the general public's proclivity to support education spending before they support programs more directly targeted to address poverty. In times of budgetary retrenchment, it is thus difficult for low-wage service sector unions to commit to pursuing a narrow education agenda.

The third challenge emerges from the fault lines separating teachers unions from low-wage service sector unions. In its crudest form, this separation emerges from class anxieties among teachers who worry about forging alliances with low-wage workers. Hence, a delegate from the American Federation of Teachers shared his concerns about the new unionism with a New York Times reporter. "Don't they realize if they really push this organizing, the labor movement is going to wind up being a movement of strawberry pickers and chicken pluckers?" (quoted in Early, 2004). 
But the divisions between teachers and other workers cannot simply be explained away as class bias. UTLA has been the preeminent-and often the sole - union voice on educational policy in Los Angeles for decades. UTLA officials feel that this historic role, alongside teachers' professional expertise, should ensure a leadership role in any collaboration. Joel Jordan of UTLA noted that he expects other unions to coordinate any education work with UTLA.

It would seem like a strange form of behavior [for 1877 to move unilaterally on educational issues]. It would seem that if those people who are really interested in school reform would want to . . . talk to the teachers union and also talk to teachers at schools. . . . If I was a local union outside of the teaching — outside of the teachers union, I would certainly—if I really was interested in pursuing reform and improvement in public education, the first place I would go to would be the teachers union and to the sister SEIU local that has members inside, who actually work with kids.

These tensions over turf have been exacerbated by competing understandings of the charter school movement. UTLA's leadership worries that some charter schools do not ensure public accountability and equitable access to all students. More pointed, the leadership views charter schools that refuse union representation to their employees as a direct threat to UTLA's power and to organized labor generally. Joel Jordan asserted that charter schools often take funds from districts and turn them over to nonunion operators, thereby harming both the teachers union and unions representing classified staff. Meanwhile, SEIU national director Andy Stern looked on charter schools as an expanding sector of the educational market that should be organized (Seewer, 2007).

Alongside this difference in perspective is the political reality that Local 1877's president Mike Garcia sits on the board of directors of Green Dot Schools, one of the major charter operators in Los Angeles. Teachers in Green Dot Schools are represented by the California Teachers Association rather than UTLA. Green Dot's CEO Steve Barr and UTLA president A. J. Duffy sparred frequently in the media when Green Dot first sought to establish charter schools in areas traditionally served by the LAUSD (Lewis, 2006). These disputes most often centered on the question of whether Green Dot selectively recruited students, but the issue of union power was never far from the surface. The public rancor has given way in recent months to a less conflictual relationship, as UTLA has focused its attention on the problems with nonunionized charters (Blume, 2008; Dillon, 2007). 


\section{Prospects and Possibilities}

The likelihood of internecine battles within the house of labor thus seems to blunt the prospects for low-wage service sector unions to move forcefully into the field of educational reform. Deputy Mayor Larry Frank noted, "Ideally, labor is not at war with itself." Is there a way forward?

SEIU staff member Saira Soto pointed toward one helpful step. Service sector unions can begin to build bridges with the teachers union around issues of common concern. Union members whose children attend poorly resourced schools have an interest in attracting and retaining quality teachers. "Teachers should get paid more, [have] less students in a class. So there are a lot of places where we overlap in terms of what we want." By entering into strategic alliances around such issues, low-wage service sector unions could begin to establish trust and a sense of goodwill that could lead to further partnerships.

UTLA chapter chair Alex Caputo-Pearl suggested a different starting point for collaboration: focusing attention on a common enemy. "I think the biggest challenge [for] ... unions, community organizations, or whomever is the ... inertia and bureaucratic sort of groupthink." He calls for a nuanced approach to charters. Although he opposes charters in principle, he understands that unionized charters can be used as a lever against district bureaucracy so teachers, parents, and community groups have greater "freedom, support, resources, and time to figure out some things for themselves and not just be beholden to the next district memo."

Although there are still many issues that need to be sorted out, the potential of low-wage service sector unions in educational reform represents a force to be reckoned with. This force has the capacity to build union membership and enhance the moral standing of unions in the broader community. It can leverage more empowered relationships with education officials and significant new resources for poorly served schools. By connecting struggles for educational equity with other campaigns of low-income workers, it advances the possibility of broader social movements. Although this vision may seem millennialist, it is not new. "What does labor want?" asked Samuel Gompers in 1893. "We want more schoolhouses and less jails; more books and less arsenals; more learning and less vice; more leisure and less greed; more justice [italics added] and less revenge; in fact, more of the opportunities to cultivate our better natures".

\section{Notes}

1. Unless otherwise noted, the quotes in this article come from interviews or focus groups conducted between 2006 and 2008 with members and leaders of the Service Employee 
International Local 1877 and Los Angeles labor and community leaders. We use pseudonyms for members of Local 1877. We identify all other labor, community, and civic leaders with their real names.

2. Data on the residential concentration of Local 1877 members come from 2006 zip code data provided by the union.

3. Our analysis of the conditions and outcomes in these 17 schools draws on the annual Education Opportunity Reports that we have coauthored with our colleagues at the Institute for Democracy, Education, and Access, University of California, Los Angeles. The reports define "severe shortages of qualified teachers," "critically overcrowded schools," and eligibility for four-year colleges. See http://www.edopp.org.

4. This estimate is based on a 2007 random sample survey of Local 1877 members. Data about the conditions and performance of these public schools are drawn from the California Basic Educational Data System.

5. The survey was funded by the University of California Labor Employment Research Fund. The Social Science Research Center at California State University, Fullerton conducted the telephone survey.

6. The sample excludes individuals for whom updated telephone information was missing from the union's membership list in April 2007 when the sample was drawn. Of eligible study participants, $67 \%$ completed the phone survey. Local 1877's represents approximately 8,000 janitors and other low-wage service workers.

7. This section draws on ongoing collaborative work with Jeannie Oakes.

8. There also has been some emerging organizing efforts that bring together progressive teachers unions with grassroots community organizing groups. The Center For Community Change in Washington, D.C., has played a key role in convening and documenting such partnerships (Dingerson, 2007).

9. In 2004, UNITE (Union of Needletrades, Industrial and Textile Employees) merged with HERE (Hotel Employees and Restaurant Employees International Union) to form UNITE HERE.

10. Education can also be said to represent an immediate interest for low-wage workers in at least two ways. First, public schools provide a set of services that affect workers' children in the here and now (their sense of self, health, and safety). Second, language classes, adult education, and community college courses can provide workers with knowledge and skills that can be used to advance their job status.

11. This quote is translated from the original Spanish.

12. See Note 11.

\section{References}

Anyon, J. (2005). Radical possibilities: Public policy, urban education and a new social movement. New York: Routledge.

Blume, H. (2008, September 19). Teachers union chief comments on Green Dot and Locke High. Los Angeles Times. Retrieved September 19, 2008, from http://latimesblogs.latimes .com/thehomeroom/2008/09/teacher-union-c.html

Della Porta, D., \& Diani, M. (1999). Social movements: An introduction. Oxford, UK: Blackwell.

Dillon, S. (2007, July 24). Maverick leads charge for charter schools. New York Times. Retrieved September 19, 2008, from http://www.nytimes.com/2007/07/24/education/24charter.html 
Dingerson, L. (2007). Organized teachers and parents: A powerful combination. Washington, DC: Center for Community Change. Retrieved September 1, 2008 at http://www.cccfiles.org/issues/education/partners/edu_secure/downloads/partnerhips_for_change_broch ure.pdf?page $=$ descriptions.

Early, S. (2004). Reutherism redux: What happens when poor workers' unions wear the color purple? Labor Advocate Online. Retrieved February 5, 2008 from http://www.kclabor.org/ reutherism_redux .htm.

Erickson, C. L., Fisk, C. L., Milkman, R., Mitchell, D. J. B., \& Wong, K. (2002). Justice for janitors in Los Angeles: Lessons from three rounds of negotiations. British Journal of Industrial Relations, 40, 543-567.

Fantasia, R. (1989). Cultures of solidarity: Consciousness, action, and contemporary American workers. Berkeley: University of California Press.

Fine, J. (2005). Community unions and the revival of the American labor movement. Politics and Society, 33(1), 153-199.

Frank, L., \& Wong, K. (2004). Dynamic political mobilization: The Los Angeles County Federation of Labor. WorkingUSA: The Journal of Labor and Society, 8, 155-181.

Frege, C., Heery, E., \& Turner, L. (2003, January). Comparative coalition building and the revitalization of the labor movement. Paper presented at the Industrial Relations Research Association conference, Washington, DC. http://www.press.uillinois.edu/journals/irra/ proceedings $2003 /$ frege.html

Gompers, S. (1893/1989). An address before the International Labor Congress in Chicago: What does labor want? In S. Kaufman and P. Albert (Series Eds.) The Samuel Gompers Papers: Volume 3. Unrest and Depression: 1891-94. (pp. 388-96) Chicago: University of Illinois Press.

Lewis, J. (2006, December 7). The secret of his success. LA Weekly. Retrieved September 19, 2008, from http://www.laweekly.com/2006-12-07/news/the-secret-of-his-success/

McAdam, D., Tarrow, S., \& Tilly, C. (2001). Dynamics of contention. New York: Cambridge University Press.

Milkman, R. (2006). L.A. story: Immigrant workers and the future of the U.S. labor movement. New York: Russell Sage.

Milkman, R. \& K. Voss. (2004). Rebuilding labor: Organizing and organizers in the new union movements. Ithaca, NY: Cornell University Press.

Nissen, B. (2004). The effectiveness and limits of labor-community coalitions: Evidence from South Florida. Labor Studies Journal, 29(1), 67-89.

Noguera, P., Ginwright, S. E., \& Cammarota, J. (2006). Beyond resistance! Youth activism and community change: New democratic possibilities for practice and policy for America's youth. New York: Routledge.

Oakes, J., \& Rogers, J. (2006). Learning power: Organizing for education and justice. New York: Teachers College Press.

Oakes, J. and Rogers, J. (2007). Radical change through radical democratic means: Organizing for equitable schools. Journal of Educational Change, 8, 193-206.

Oakes, J., Rogers, J., Blasi, G., \& Lipton, M. (in press). Grassroots organizing, social movements, and the right to high-quality education. Stanford Journal of Civil Rights and Civil Liberties.

Orfield, G. \& S. Eaton. (1996). Dismantling desegregation: The quiet reversal of Brown $v$. Board of Education. New York, NY: New Press.

Orr, M. (2007). Community organizing and the changing ecology of civic engagement. In M. Orr (Ed.), Transforming the city: Community organizing and the challenge of political change (pp. 1-27). Lawrence: University Press of Kansas. 
Rogers, J., \& Oakes, J. (2005). John Dewey speaks to Brown: Research, democratic social movement strategies, and the struggle for education on equal terms. Teachers College Record, 107(9), 2178-2203.

Seewer, J. (2007, April 15). Leader guides breakaway SEIU. San Mateo County Times. Retrieved November 1, 2008 from http://iw.newsbank.com/iw-search/we/InfoWeb?p_action=doc\&p_ heme $=$ aggdocs $\&$ p_topdoc $=1 \&$ p_docnum $=1 \&$ p_sort $=Y M D \_d a t e: D \& p \_p r o d u c t=$ AWNB\&p_docid=1188D7A0E36A21B0\&p_text_direct-0=document_id= (\%201188D7A0E36A21B0\%20)\&p_nbid=I61C61EVMTIyNjM4MTU5MS42MDgzNjQ6 MToxMDoxMjguOTcuMC4w

Shirley, D. (2002). Valley interfaith and school reform: Organizing for power in south Texas. Austin: University of Texas Press.

Tattersall, A. (2006). A little help from our friends: A framework for understanding when labor unions are likely to join long-term union-community coalitions. Union Ideas Network. Retrieved February 5, 2008 from http://uin.org.uk/dmdocuments/2006-10-16-23-35tattersall\%20a\% 20little\%20help\%20from\%20our\%20friends\%20distribute.pdf

Tattersall, A., \& Reynolds, D. (2007). The shifting power of labor-community coalitions: Identifying common elements of powerful coalitions in Australia and the U.S. WorkingUSA: The Journal of Labor and Society, 10(1), 77-102.

Turner, L. (2007). An urban resurgence of social unionism. In L. Turner \& D. Cornfield (Eds.), Labor in the new urban battlegrounds: Local solidarity in a global economy (pp. 1-20). Ithaca, NY: Cornel University Press.

University of California, Los Angeles, Institute of Industrial Relations. (2006, February). Attitudes about labor unions: Los Angeles County residents. Los Angeles: Author.

Voss, K., \& Sherman, R. (2000). Breaking the iron law of oligarchy: Union revitalization in the American labor movement. American Journal of Sociology, 106, 303-349.

Waldinger, R., Erickson, C. L., Milkman, R., Mitchell, D. J. B., Valenzuela, A., Wong, K., et al. (1998). Helots no more: A case study of the justice for janitors campaign in Los Angeles. In K. Bronfenbrenner, S. Friedman, R. W. Hurd, R. A. Oswald, \& R. L. Seeber (Eds.), Organizing to win (pp. 102-119). Ithaca, NY: Cornell University Press.

Warren, M. (2001). Dry bones rattling: Community building to revitalize American democracy. Princeton, NJ: Princeton University Press.

Warren, M. (in press). Community organizing for educational reform. In M. Orr \& J. Rogers (Eds.), Public engagement for public education. Palo Alto, CA: Stanford University Press.

Wong, K., \& Munoz, C. (2004). Don't miss the bus: The immigrant workers' freedom ride. New Labor Forum, 13(2), 61-66.

John Rogers is an associate professor in UCLA's Graduate School of Educationand Information Studies and the director of UCLA's Institute for Democracy, Education and Access (IDEA).Rogers also serves as the faculty co-director of UCLA's Principal Leadership Institute. He studies public engagement and community organizing as strategies for equityfocused school reform and democratic renewal. He draws extensively on the work of John Dewey to explore the meaning of, and possibilities for, democratic education today.

Veronica Terriquez is a $\mathrm{PhD}$ candidate in the Department of Sociology at UCLA. Her research focuses on schooling inequalities, civic engagement in schools and labor unions, and immigrant integration. 